\title{
PENGARUH CARA DISTRIBUSI PENCAHAYAAN BUATAN PADA KENYAMANAN BERCENGKERAMA PENGUNJUNG KAFE
}

\author{
Martin Sena Kristian, Leonardo, Erwin Ardianto Halim \\ (Email: martinsena22@yahoo.com) \\ Jurusan Desain Interior \\ Fakultas Seni Rupa dan Desain \\ Universitas Kristen Maranatha \\ JL. Prof. Drg. Surya Sumantri No.65, Bandung, Jawa Barat, 40164, Indonesia
}

\begin{abstract}
ABSTRAK
Kafe bagi kaum muda masa kini tidak lagi sekedar tempat makan semata namun telah bergeser menjadi tempat bersosialisasi. Suasana kafe dibuat senyaman mungkin bagi mereka untuk bercengkerama melalui penataan cahaya sebagai pendukungnya. Penelitian ini bertujuan untuk melihat pilihan responden atas cara distribusi pencahayaan buatan pada kenyamanan bercengkerama pengunjung kafe dengan meminta 60 responden anak muda untuk menentukan suasana pencahayaan kafe ternyaman dari lima pilihan ilustrasi yang didasarkan pada teori ILO (1998) serta teori Grondzik dan Kwok (2010). Hasil menunjukkan bahwa indirect lighting yang menempel dinding dan plafon kafe paling disukai dalam menciptakan suasana yang mendukung untuk bercengkerama.
\end{abstract}

Kata kunci: bercengkerama; distribusi cahaya; kafe; kenyamanan

\section{ABSTRACT}

Nowadays, young people like Cafe more as a place for socializing than merely for eating. Its environment is made to comfort them through lighting design. This research aims to describe lighting distribution type from users choice of comfort while socializing in a café. The method is to ask 60 persons to choose the most comfortable lighting environment from five given illustrations based on a theory by ILO (1998) and Grondzik and Kwok (2010) theory. The result shows indirect lighting from wall and ceiling as the most preferred lighting distribution to support comfort while socializing.

Keywords: café; comfort; lighting distribution; socializing

\section{PENDAHULUAN}

Kafe di era modern semakin menjamur di kota-kota besar. Hal ini terjadi karena adanya perubahan gaya hidup di masyarakat perkotaan. Gaya hidup modern dari masyarakat perkotaan telah menjadikan kafe untuk dituntut semakin menarik. Daya tarik sebuah kafe dapat ditentukan sesuai dengan ekspektasi awal dari fungsi kafe tersebut yang tentu saja dapat bermacam-macam, di antaranya adalah untuk bercengkerama. 
Kebutuhan untuk bercengkerama dibutuhkan oleh setiap orang dan dapat dilakukan di mana saja. Namun sesuai dengan fenomena yang terjadi seperti yang dilansir dalam www.barometerrakyat.com bahwa: "remaja sekarang lebih suka duduk di tempat yang menarik seperti kursi, meja, tata lampu, serta minuman dan makanan nya yang menarik walaupun rasa dari makanan dan minuman di kafe biasa-biasa saja." Dari fenomena tersebut, maka kebutuhan dari masyarakat untuk bercengkerama telah beralih ke kafe yang dapat menyediakan semua fasilitas dengan baik. Namun tidak semua fasilitas dapat menunjang fungsi bercengkerama dengan baik. Tanpa distribusi cahaya yang baik, maka kegiatan mengobrol-pun akan terganggu.

Jurnal ilmiah ini akan membahas salah satu faktor penunjang kegiatan bercengkerama serta kaitannya dengan peletakan lampu pada distribusi cahaya terhadap kenyamanan pengunjung kafe.

\section{METODE PENELITIAN}

Jenis penelitian yang dilakukan adalah penelitian deskriptif-kuantitatif dengan 60 orang yang akan dipilih secara acak akan diberikan kuesioner. Kuesioner berisi gambar-gambar dari lima cara distribusi pencahayaan berdasarkan teori ILO, 1998 serta buku Grondzik dan Kwok (2010) tentang direct lighting, semi direct lighting, general diffuse lighting, semi indirect lighting, serta indirect lighting beserta penjelasan dari kelima cara distribusi cahaya tersebut. ILO (International Labour Organization) merupakan organisasi buruh berskala internasional. Organisasi tersebut memberikan standar mengenai cara distribusi pencahayaan dan didukung oleh buku Grondzik dan Kwok yaitu Mechanical and Electrical Equipment for Buildings.

\section{Definisi Pencahayaan Buatan}

Menurut Santoso, peran pencahayaan tidak lagi sekedar memberi penerangan tetapi juga menonjolkan estetika dan atmosfer ruangan, memanjakan mata, bahkan dapat mempengaruhi citra interior maupun arsitektur bangunan. Desain pencahayaan atau lighting kini semakin penting dalam rancangan dan pengerjaan proyek. Kesadaran akan peran tata lampu pada bangunan juga didukung oleh perkembangan teknologi yang menghasilkan efek dramatis yang ditimbulkan oleh arah jatuhnya cahaya, perbedaan warna cahaya dan letak armatur lampu. Pencahayaan buatan adalah pencahayaan yang 
bersumber dari sumber cahaya yang tidak alami (matahari). Pada cuaca yang kurang baik dan malam hari, pencahayaan buatan sangat dibutuhkan untuk menunjang aktivitas manusia. Lechner (2001) mengatakan bahwa perkembangan teknologi sumber cahaya buatan memberikan kualitas pencahayaan buatan yang memenuhi kebutuhan manusia. Hal ini terbukti dari banyaknya jenis cahaya buatan (lampu) yang dapat digunakan oleh manusia saat ini. Apabila pada zaman dahulu manusia hanya menggunakan lampu untuk menerangi aktivitasnya, saat ini lampu juga digunakan sebagai sarana untuk mencapai kenyamanan yang berkaitan akan respon manusia terhadap estetika. Dwimirnani (2010) dalam bukunya Tata Cahaya Interior Rumah Tinggal mengatakan bahwa tata cahaya ruang interior memiliki tujuan praktis memberikan kenyamanan bagi penggunanya. Kenyamanan tersebut dapat dicapai dengan cara memenuhi kebutuhan terhadap fungsi dan estetika. Dengan kata lain, selain kebutuhan manusia akan fungsi pencahayaan, namun saat ini manusia juga memiliki kebutuhan lain akan tata cahaya yaitu estetika yang membuat manusia dapat merasa nyaman.

\section{Definisi Kenyamanan}

Kolcaba (1992) mengungkapkan kenyamanan/rasa nyaman adalah suatu keadaan telah terpenuhinya kebutuhan dasar manusia yaitu kebutuhan akan ketenteraman (suatu kepuasan yang meningkatkan penampilan sehari-hari), kelegaan (kebutuhan telah terpenuhi), dan transenden (keadaan tentang sesuatu yang melebihi masalah dan nyeri). Kenyamanan mesti dipandang secara holistik yang mencakup empat aspek yaitu, fisik berhubungan dengan sensasi tubuh. Sosial, berhubungan dengan hubungan interpersonal, keluarga, dan sosial. Psikospiritual, berhubungan dengan kewaspadaan internal dalam diri sendiri yang meliputi harga diri, seksualitas, dan makna kehidupan. Lingkungan, berhubungan dengan latar belakang pengalaman eksternal manusia seperti cahaya, bunyi, temperatur, warna, dan unsur alamiah lainnya (Potter \& Perry, 2005). Berdasarkan pernyataan tersebut cahaya memiliki peranan dalam kenyamanan lingkungan. Kenyamanan juga berhubungan terhadap privasi, ruang personal, dan teritorialitas bagi masing-masing individu.

\section{Pengelompokan Distribusi Pencahayaan}

Berdasarkan cara distribusi cahayanya, pencahayaan menurut ILO (1998) dalam Wibiyanti (2008) serta Grondzik dan Kwok (2010) dapat dibedakan menjadi lima macam, yaitu: 
a. Distribusi pencahayaan langsung (direct lighting)

Pada sistem pencahayaan langsung, sebanyak 90 - 100\% cahaya diarahkan secara langsung ke benda-benda yang perlu diterangi.

\section{b. Distribusi pencahayaan semi langsung (semi direct lighting)}

Pada sistem pencahayaan semi langsung, sebanyak 60 - 90\% cahaya diarahkan langsung kepada benda-benda yang perlu diterangi, sedangkan sisanya akan dipantulkan ke langitlangit dan dinding.

c. Distribusi pencahayaan difus (general diffuse lighting)

Pada sistem pencahayaan difus, sebanyak 40 - 60\% cahaya diarahkan kepada permukaan yang perlu diterangi, selebihnya lagi menerangi langit-langit dan dinding untuk kemudian dipantulkan.

\section{d. Distribusi pencahayaan semi tidak langsung (semi indirect lighting)}

Pada sistem pencahayaan semi tidak langsung, sebanyak 60 - 90\% cahaya diarahkan ke langit-langit dan dinding bagian atas dan sisanya ke bawah. Dengan demikian, langit-langit memerlukan perhatian lebih dengan dilakukannya pemeliharaan yang baik

\section{e. Distribusi pencahayaan tidak langsung (indirect lighting)}

Pada sistem pencahayaan tidak langsung, sebanyak 90 - 100\% cahaya diarahkan ke langitlangit dan dinding bagian atas kemudian dipantulkan untuk menerangi seluruh ruangan. Agar seluruh langit-langit dapat dijadikan sumber cahaya, maka diperlukan pemeliharaan yang baik.

\section{Penataan Pencahayaan yang Baik}

Menurut Indrani (2010), syarat-syarat bagi penataan cahaya lampu yang baik, antara lain:

1. Nyaman, artinya tidak menimbulkan keletihan pada mata.

2. Efisien, artinya tidak membuang-buang sinar dengan percuma, sesuai kebutuhan.

3. Sesuai, artinya cocok dengan atmosfer ruang yang ingin diciptakan.

Menurut Cayless \& Marsden (1966) dinyatakan bahwa kuat penerangan yang merata (uniformity of illuminance) adalah penting karena tiga hal, yaitu dapat mengurangi variasi kuat penerangan dalam ruang dengan aktivitas sejenis; kepadatan cahaya dapat 
mempengaruhi kinerja dan kenyamanan visual; pencahayaan yang tidak merata tidak memuaskan secara subjektif.

Dalam kuesioner, responden akan diberi pertanyaan yaitu: "Cara distribusi manakah yang menurut anda paling cocok digunakan untuk menciptakan kenyamanan dari segi privasi?" Kemudian setelah itu, responden akan memberi skor dari kelima gambar tersebut seperti yang terdapat pada tabel berikut:

Tabel 1. Penjabaran Respon beserta Skornya

\begin{tabular}{|c|c|}
\hline Respon & Skor \\
\hline Sangat Nyaman & 5 \\
\hline Nyaman & 4 \\
\hline Biasa & 3 \\
\hline Tidak Nyaman & 2 \\
\hline Sangat Tidak Nyaman & 1 \\
\hline
\end{tabular}

Hasil akhirnya akan dihitung berdasarkan skor yang telah ditentukan. Maka, hasil yang paling mendekati 300 adalah jenis distribusi cahaya ternyaman sebab apabila 60 responden memberikan skor 5 pada salah satu distribusi cahaya, maka skor maksimal yang akan didapatkan adalah 300. Namun apabila skor yang didapatkan adalah 60, maka telah dapat dipastikan bahwa jenis distribusi cahaya tersebut sangat tidak nyaman. Dari hal tersebut dapat ditentukan pula bahwa batas aman yang paling minimal untuk menyatakan sebuah pencahayaan dapat digunakan berdasarkan distribusi pencahayaannya adalah di skor 180 karena 180 merupakan batas tengah dari skor 60-300. 
HASIL DAN PEMBAHASAN

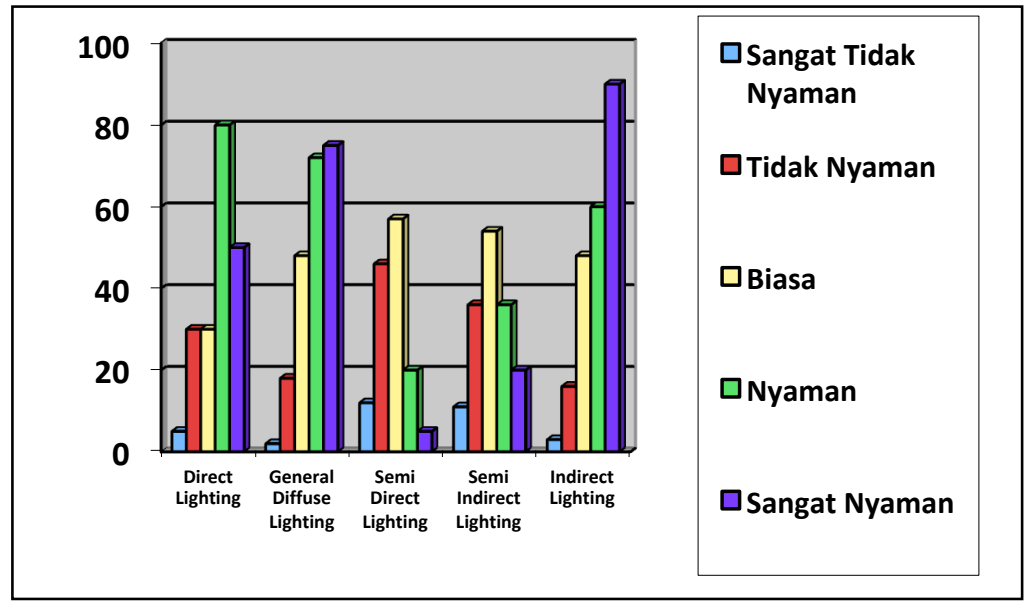

Gambar 1. Grafik 1 Pilihan Responden Atas Kelima Cara Distribusi Cahaya

Grafik 1 menunjukkan kecenderungan responden dalam memilih distribusi cahaya yang dipaparkan dalam kuesioner. Dalam grafik dapat terlihat masing-masing distribusi cahaya berdasarkan tingkat kenyamanannya. Angka dengan skor 90 adalah skor tertinggi yang didapatkan oleh pencahayaan indirect lighting. Namun bukan berarti angka tersebut sudah dapat menentukan cara distribusi cahaya ternyaman karena setelah itu seluruh skor pada masing-masing pencahayaan akan dijumlahkan yang kemudian dipaparkan pada grafik 2. (detail kuesioner pada lampiran)

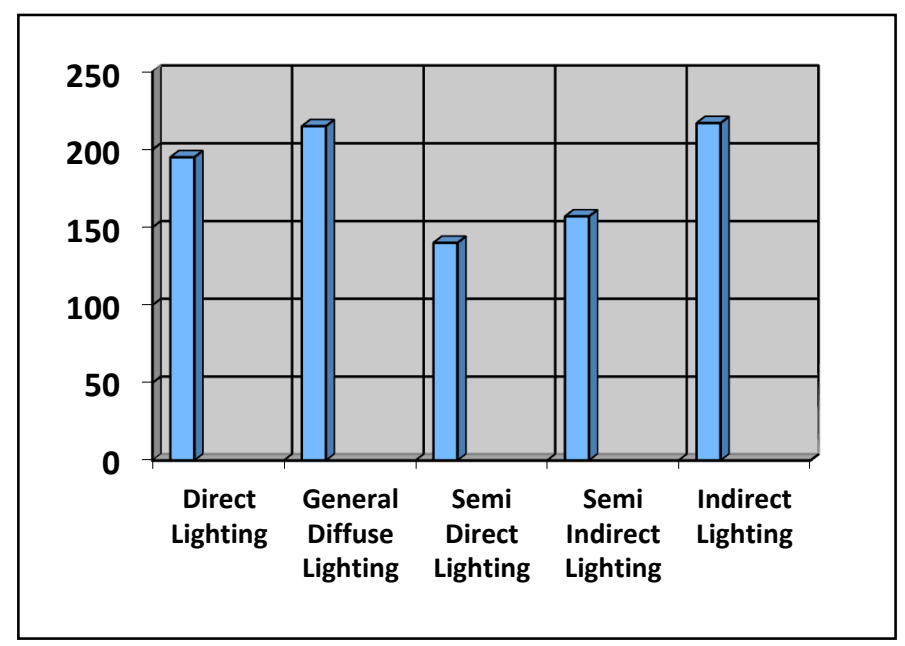

Gambar 2. Grafik 2 Tingkat Kenyamanan Cara Distribusi Cahaya Berdasarkan Kuesioner

Grafik 2 menunjukkan tingkat kenyamanan dari kelima distribusi cahaya berdasarkan skor dari masing-masing respon sebagaimana yang telah dijelaskan dalam metode penelitian (lihat Tabel 1). Sebelum melihat pada grafik 2, telah dipaparkan dalam grafik 1 mengenai 
detail masing-masing pilihan responden yang kemudian disederhanakan dengan cara menjumlahkan skor-skor tersebut pada grafik 2 (detail kuesioner pada lampiran). Melalui kedua grafik di atas, maka hasil penelitian dapat dijabarkan melalui gambar-gambar sebagai berikut: (gambar yang dicantumkan merupakan gambar yang ditunjukkan kepada responden)

\section{Direct Lighting}

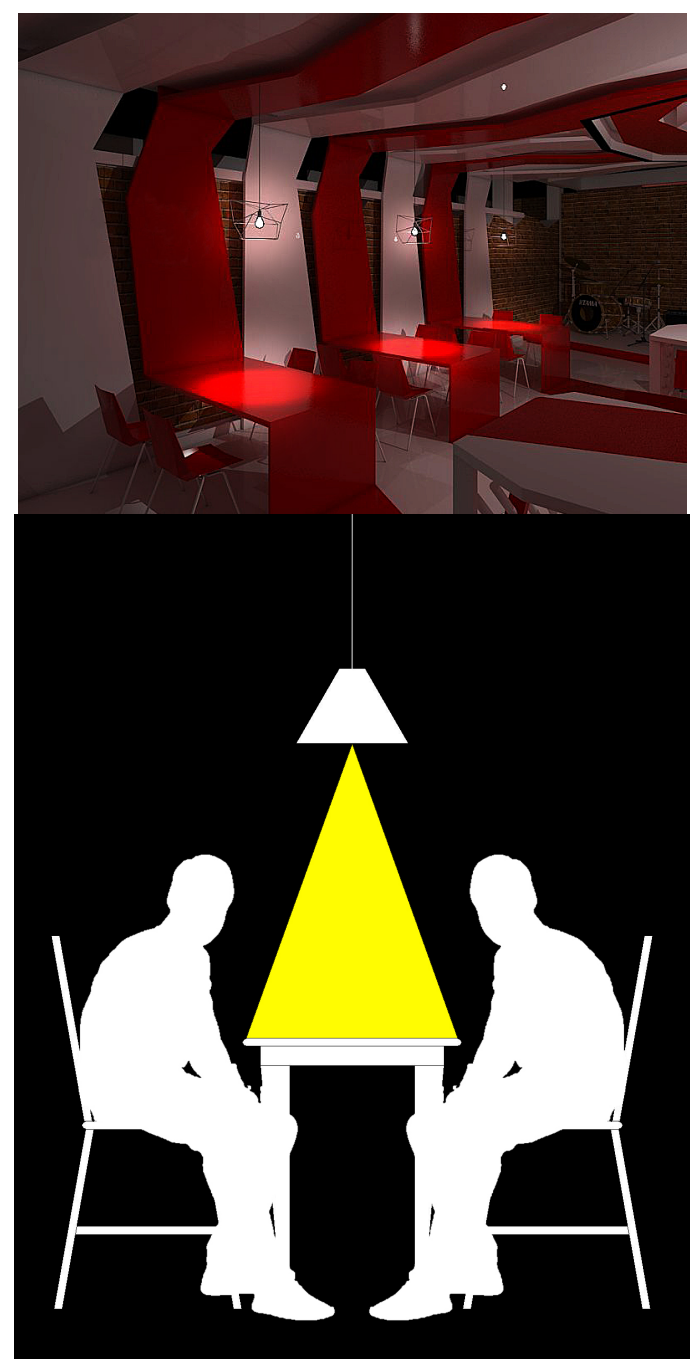

Gambar 3. Direct Lighting

Pencahayaan Direct Lighting cenderung nyaman menurut responden. Berdasarkan Grafik 1, respon nyaman menjulang di antara distribusi cahaya lainnya. Kemudian dari Grafik 2 juga dapat terlihat bahwa direct lighting mendekati angka 200 yang merupakan batas aman dalam tingkat kenyamanannya. 


\section{General Diffuse Lighting}

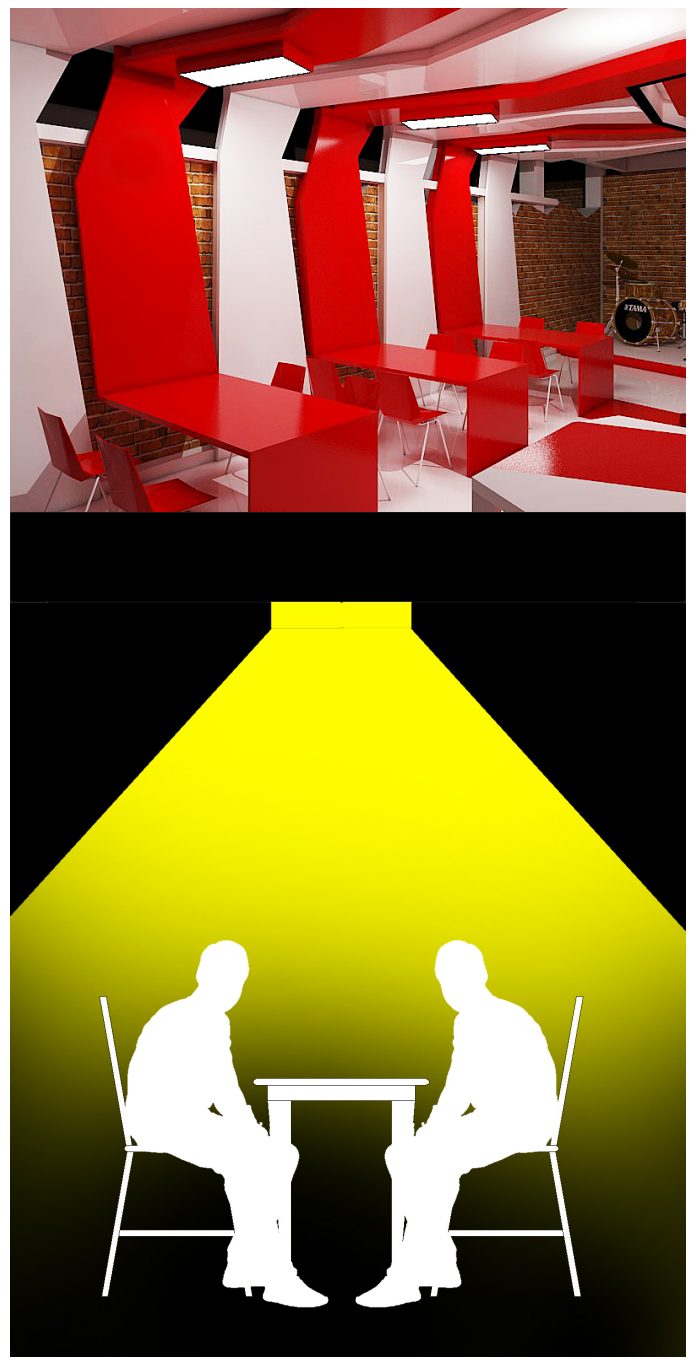

Gambar 4. General Diffuse Lighting

Pencahayaan General Diffuse Lighting juga dapat dikatakan nyaman. Berdasarkan Grafik 1, General Diffuse Lighting memiliki respon yang cukup berimbang antara respon nyaman serta sangat nyaman. Demikian pula dapat terlihat pada Grafik 2, General Diffuse Lighting memiliki skor melebihi angka 200 yang dapat dikatakan memiliki tingkatan nyaman. 


\section{Semi Direct Lighting}

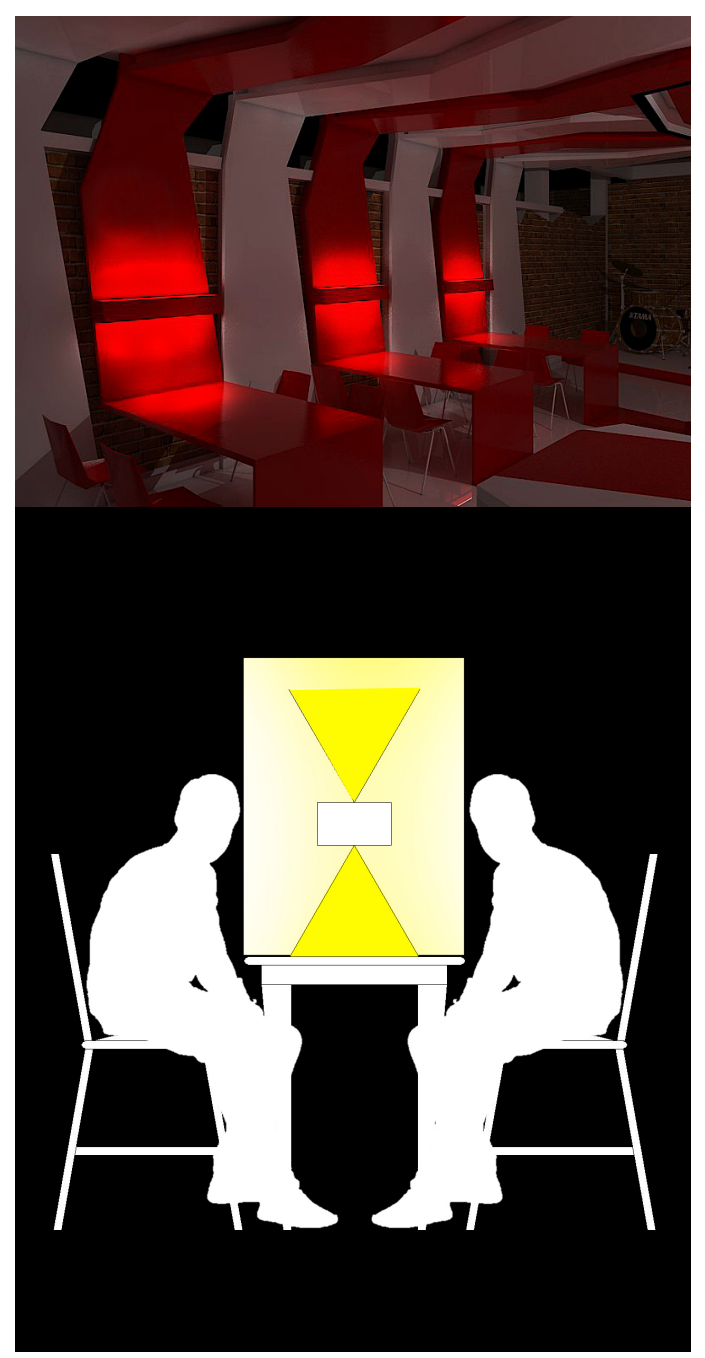

Gambar 5. Semi Direct Lighting

Pencahayaan Semi Direct Lighting cenderung tidak nyaman menurut responden. Pada Grafik 1 dapat terlihat bahwa responden cenderung memilih biasa serta tidak nyaman. Kemudian respon tidak nyaman paling sering diberikan pada semi direct lighting dibanding pencahayaan lainnya. Pada Grafik 2 juga dapat dilihat bahwa semi direct lighting menempati tingkatan paling akhir atau dengan kata lain paling tidak nyaman. 


\section{Semi Indirect Lighting}

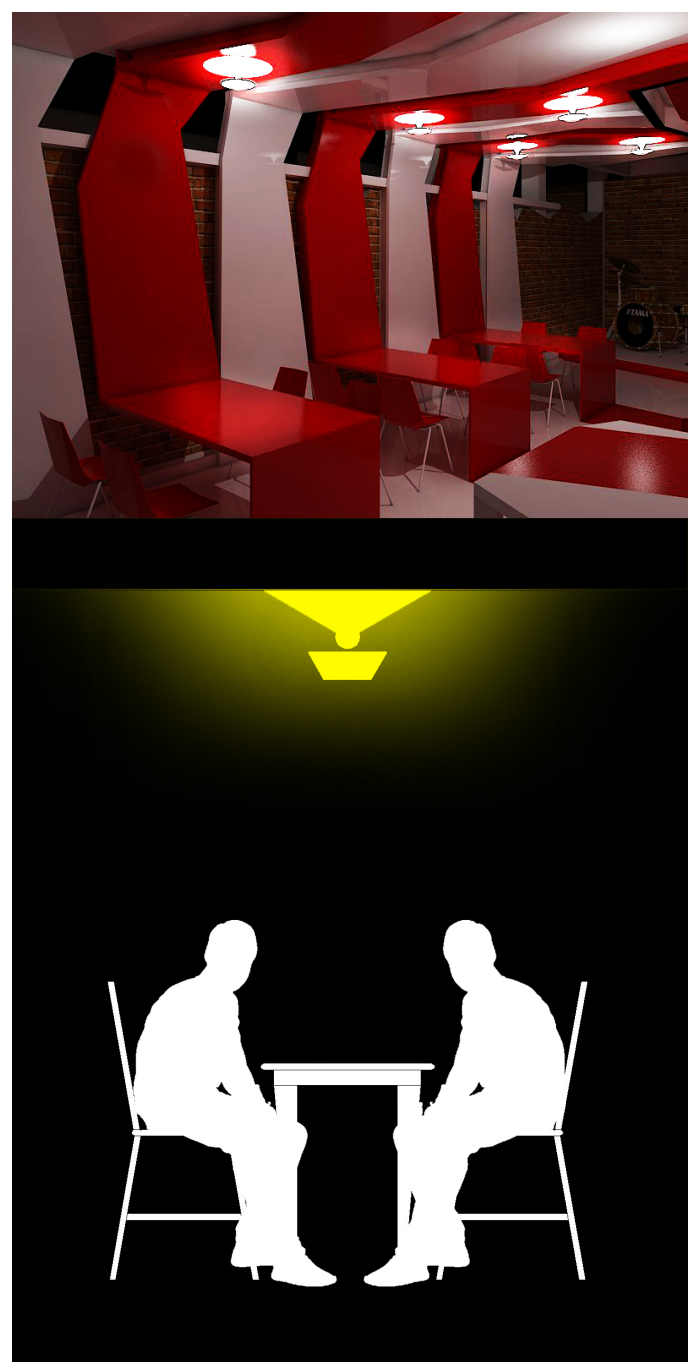

Gambar 5. Semi Indirect Lighting

Cara distribusi pencahayaan Semi Indirect Lighting cenderung tidak nyaman. Kebanyakan responden memilih biasa hingga sangat tidak nyaman seperti yang dapat dilihat pada Grafik 1. Pada Grafik 2 juga dapat terlihat bahwa pencahayaan berada pada tingkatan tidak nyaman. 


\section{Indirect Lighting}

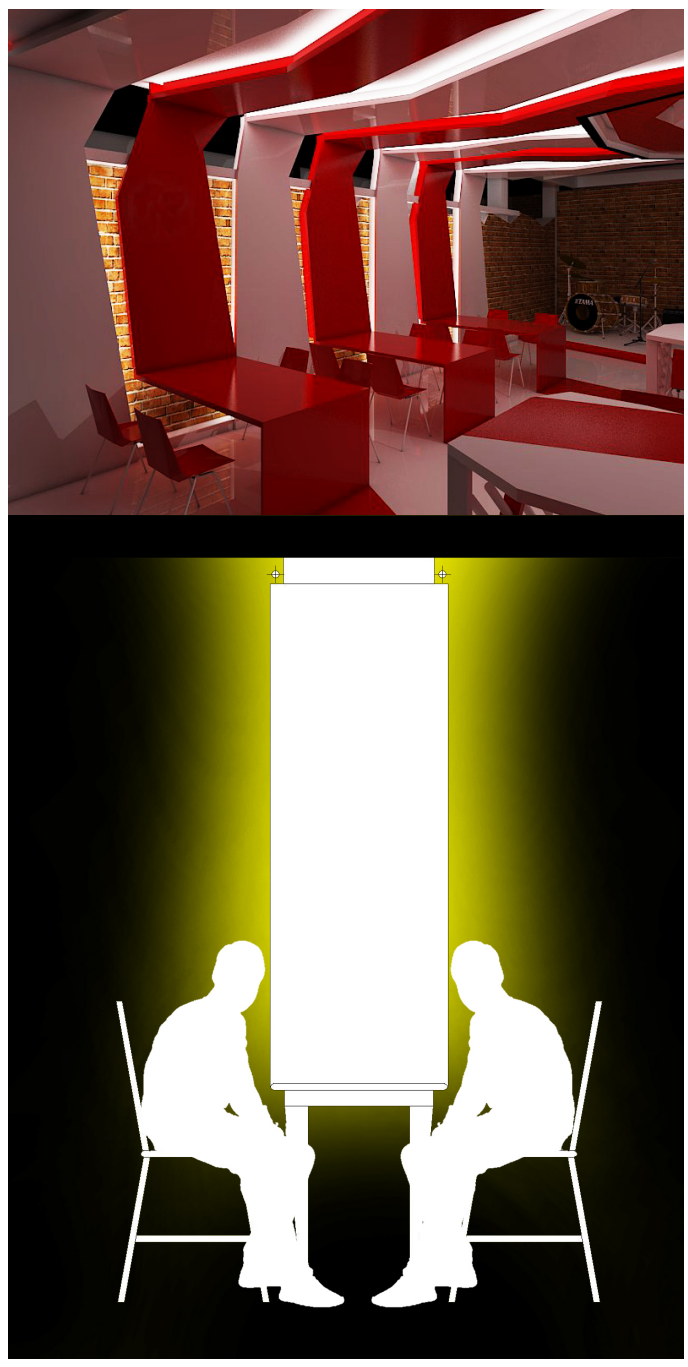

Gambar 6. Indirect Lighting

Indirect Lighting adalah jenis distribusi cahaya yang ternyaman. Pada Grafik 1, pilihan responden mayoritas adalah sangat nyaman. Hasil itu juga merupakan yang terbanyak dibanding pencahayaan lainnya seperti yang dapat dilihat pada grafik 1. Grafik 2 juga menunjukkan bahwa pencahayaan ini sangat nyaman.

Berbasis data yang telah didapatkan, dapat diurutkan bahwa cara distribusi cahaya yang paling nyaman menurut responden yang telah mengisi kuesioner adalah sebagai berikut: 
Tabel 2. Urutan Distribusi Cahaya yang Ternyaman hingga yang Tidak Nyaman

\begin{tabular}{|l|l|l|}
\hline No. & Distribusi Cahaya & Skor \\
\hline 1. & Indirect Lighting & 217 \\
\hline 2. & General Diffuse Lighting & 215 \\
\hline 3. & Direct Lighting & 195 \\
\hline 4. & Semi Indirect Lighting & 157 \\
\hline 5. & Semi Direct Lighting & 140 \\
\hline
\end{tabular}

Indirect Lighting serta General Diffuse Lighting hanya berbeda tipis. Hal ini dapat menunjukkan keduanya merupakan favorit dari responden. Demikian pula dengan Direct Lighting, meskipun berbeda 20 poin dari General Diffuse, ada kecenderungan responden untuk memilih jenis pencahayaan Direct Lighting sebagai pencahayaan yang nyaman. Hal signifikan yang dapat dilihat dari data di atas adalah posisi Semi Indirect Lighting serta Semi Direct Lighting yang cenderung tidak disukai oleh responden. Data menunjukkan, perbedaan poin antara Direct Lighting serta Semi Indirect mencapai 38 poin. Hal ini menunjukkan bahwa cara pencahayaan semi indirect serta semi direct, tidak cocok untuk digunakan karena tidak nyaman membangun kenyamanan serta privasi dalam bercengkerama.

\section{PENUTUP}

Indirect Lighting adalah cara distribusi cahaya ternyaman berdasarkan data yang diperoleh. Meskipun hasil akhir yang didapatkan tidak terlalu signifikan dibandingkan General Diffuse Lighting dengan perbedaan 2 poin, skor indirect lighting dalam pemilihan opsi "sangat nyaman", memiliki margin yang signifikan dibandingkan general diffuse lighting. Hal ini membuktikan bahwa jenis distribusi cahaya pada kafe dalam menciptakan kenyamanan untuk bercengkerama adalah jenis indirect lighting. Dapat disimpulkan pula bahwa jenis pencahayaan yang lebih menyebar dapat menciptakan kenyamanan dalam bercengkerama. Dalam hal ini, terbukti bahwa cara distribusi direct lighting, semi indirect lighting, serta semi direct lighting yang pencahayaannya cenderung terfokus pada titik tertentu, memiliki poin yang jauh lebih kecil dibandingkan jenis indirect lighting serta general diffuse lighting yang cara distribusinya lebih menyebar. Pernyataan ini diperkuat dengan teori Indrani (2010) yang menyatakan bahwa syarat-syarat bagi penataan cahaya lampu yang nyaman adalah tidak menimbulkan keletihan pada mata, kemudian teori 
Cayless \& Marsden (1966) yang menyatakan bahwa kuat penerangan yang merata (uniformity of illuminance) adalah penting karena tiga hal, yaitu dapat mengurangi variasi kuat penerangan dalam ruang dengan aktivitas sejenis; kepadatan cahaya dapat mempengaruhi kinerja dan kenyamanan visual; pencahayaan yang tidak merata tidak memuaskan secara subjektif.

\section{DAFTAR PUSTAKA}

Cayless, M.A. dan Marsden, 1983. A.M., Lamps and Lighting : A Manual of Lamps and Lighting, 3rd ed., Edward Arnold Ltd., London.

Dwimirnani, Putri dan Mariana Rahman. 2010. Tata Cahaya Interior Rumah Tinggal. Jakarta: PT. Penebar Swadaya Wisma Hijau.

Effendi, Mohammad Putra Rianto dan Abraham Seno. Pengaruh Lampu Spotlight Terhadap Ketertarikan Pengunjung Toko Pakaian Altos Kemang. Jakarta: Universitas Mercu Buana.

Grondzik, Walter T., dan Alison G. Kwok, Benjamin Stein, John S. Reynolds. 2010. Mechanical and Electrical Equipment for Building Eleventh Edition. Amerika Serikat: John Wiley and Sons, Inc.

Indrani, Hedy. 2010. Sistem Tata Cahaya, Bahan Kuliah: Fisika Bangunan. Surabaya: Universitas Kristen Petra.

Kurniawati, Lia. 2008. Pengaruh Pencahayaan LED Terhadap Suasana Ruang Cafe dan Restoran. Depok: Universitas Indonesia.

Phillips Lighting. 1993. Lighting Manual Fifth Edition. Netherlands: Philips Lighting B. V.

Potter dan Perry. 2005. Buku Ajar Fundamental Keperawatan Edisi 4. Jakarta: EGC.

Wibiyanti, Puspa Indah. 2008. Kajian Pencahayaan pada Industri Kecil Pakaian Jadi dan Pembuatan Tas di Perkampungan Industri Kecil, Penggilingan Tahun 2008. Depok: Universitas Indonesia.

Widodo, Tri Wahyu. 2016. Fenomena Kafe Sebagai Gaya Hidup Kalangan Remaja Perkotaan di Tanjungpinang. Diunduh 10 Maret 2017. 


\section{LAMPIRAN}

Tabel 3. Penilaian Responden pada Simulasi Direct Lighting pada Area Kafe

\begin{tabular}{|c|c|c|c|}
\hline Respon & $\begin{array}{c}\text { Jumlah } \\
\text { Orang }\end{array}$ & Skor & Total \\
\hline Sangat Nyaman & 10 & 5 & 50 \\
\hline Nyaman & 20 & 4 & 80 \\
\hline Biasa & 10 & 3 & 30 \\
\hline Tidak Nyaman & 15 & 2 & 30 \\
\hline Sangat Tidak & 5 & 1 & 5 \\
\hline \multicolumn{2}{|c|}{ Tyaman } & & 195 \\
\hline
\end{tabular}

Tabel 4. Penilaian Responden pada Simulasi General Diffuse Lighting pada Area Kafe

\begin{tabular}{|c|c|c|c|}
\hline Respon & $\begin{array}{l}\text { Jumlah } \\
\text { Orang }\end{array}$ & Skor & Total \\
\hline Sangat Nyaman & 15 & 5 & 75 \\
\hline Nyaman & 18 & 4 & 72 \\
\hline Biasa & 16 & 3 & 48 \\
\hline Tidak Nyaman & 9 & 2 & 18 \\
\hline $\begin{array}{c}\text { Sangat Tidak } \\
\text { Nyaman }\end{array}$ & 2 & 1 & 2 \\
\hline \multicolumn{3}{|c|}{ Total Skor Akhir } & 215 \\
\hline
\end{tabular}

Tabel 5. Penilaian Responden pada Simulasi Semi Direct Lighting pada Area Kafe

\begin{tabular}{|c|c|c|c|}
\hline Respon & $\begin{array}{c}\text { Jumlah } \\
\text { Orang }\end{array}$ & Skor & Total \\
\hline Sangat Nyaman & 1 & 5 & 5 \\
\hline Nyaman & 5 & 4 & 20 \\
\hline Biasa & 19 & 3 & 57 \\
\hline Tidak Nyaman & 23 & 2 & 46 \\
\hline Sangat Tidak & 12 & 1 & 12 \\
Nyaman & & & 140 \\
\hline \multicolumn{2}{|c|}{ Total Skor Akhir } & \\
\hline
\end{tabular}


Pengaruh Cara Distribusi Pencahayaan Buatan Pada Kenyamanan Bercengkerama Pengunjung Kafe

Tabel 6. Penilaian Responden pada Simulasi Semi Indirect Lighting pada Area Kafe

\begin{tabular}{|c|c|c|c|}
\hline Respon & $\begin{array}{c}\text { Jumlah } \\
\text { Orang }\end{array}$ & Skor & Total \\
\hline Sangat Nyaman & 4 & 5 & 20 \\
\hline Nyaman & 9 & 4 & 36 \\
\hline Biasa & 18 & 3 & 54 \\
\hline Tidak Nyaman & 18 & 2 & 36 \\
\hline $\begin{array}{c}\text { Sangat Tidak } \\
\text { Nyaman }\end{array}$ & 11 & 1 & 11 \\
\hline \multicolumn{2}{|c|}{ Total Skor Akhir } & 157 \\
\hline
\end{tabular}

Tabel 7. Penilaian Responden pada Simulasi Indirect Lighting pada Area Kafe

\begin{tabular}{|c|c|c|c|}
\hline Respon & $\begin{array}{c}\text { Jumlah } \\
\text { Orang }\end{array}$ & Skor & Total \\
\hline Sangat Nyaman & 18 & 5 & 90 \\
\hline Nyaman & 15 & 4 & 60 \\
\hline Biasa & 16 & 3 & 48 \\
\hline Tidak Nyaman & 8 & 2 & 16 \\
\hline $\begin{array}{c}\text { Sangat Tidak } \\
\text { Nyaman }\end{array}$ & 3 & 1 & 3 \\
\hline \multicolumn{2}{|c|}{ Total Skor Akhir } & 217 \\
\hline
\end{tabular}

